\title{
rudolf p botha
}

the world of language

1 its crust

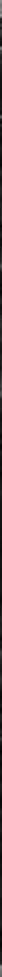

\section{no 241994}




\section{THE WORLD OF LANGUAGE}

\section{ITS CRUST}

by

Rudolf P. Botha

SPIL PLUS 24

1994 
This is the first of a series of studies in 'linguistic cosmology'. I would like to thank Cecile le Roux, Walter Winckler, Christine Smit, Jacqui du Toit, Lize Venter and Theresa Biberauer for their generous support.

R.P.B. 
CONTENTS

PREFACE: OF KINGS AND COSMOLOGISTS

INTRODUCTION: A GRAND SURVEY

PART 1 - LAYERS: FROM CRUST TO CORE 6

1 Language products $\quad 7$

1.1 Linguistic utterances 7

1.1.1 Utterance signals 8

1.1.2 Utterance meanings 13

1.2 Linguistic judgements 17

1.3 Texts and discourses 20

1.4 Crusthood 22

Notes to Preface 23

Notes to Chapter $1 \quad 24$

$\begin{array}{ll}\text { Bibliography } & 27\end{array}$ 


\title{
PREFACE: OF KINGS AND COSMOLOGISTS
}

\author{
'All this time the Guard was looking at [Alice], first \\ through a telescope, then through a microscope, and then \\ through an opera-glass'. \\ [Lewis Carroll, Through the Looking-Glass, p.218]
}

Nobody was too surprised when All The King's Men failed to put it together again. But, when All The King's Horses couldn't do the trick either, we realized that we had a major problem on our hands. It all started when we, a bunch of ordinary linguists, were asked to draw a picture of the world of language as a whole: a simple picture showing its large-scale features and the way they hang together. To our acute embarrassment, we found ourselves unable to deliver.

'But', you might wonder, 'isn't producing a picture of this sort part of the very stockin-trade of linguists?' In terms of what linguists profess to be doing, yes indeed. But, in terms of how they routinely spend their days, certainly not. As ordinary linguists, you see, we had been bent only on taking the world of language apart, not on piecing it together again. And, in the spirit of the trade, we had been looking at ever smaller bits of this world. In fact, we became so glued to our microscopes that we completely forgot to step back once in a while to view the whole from a suitable distance. This was the root of our predicament.

At first we reckoned that the required picture was easy to get hold of. One of us, I can't remember who, suggested that we 'simply do the obvious thing': tap the King's resources. So we summoned All The King's Men. (Four thousand two hundred and seven of them there were, if the White Monarch's last count was anything to go by). That is, we consulted the loads of linguistics textbooks that were supposed to 'provide a systematic introduction to language in general'. We looked at them all: in twos and threes at first, then in twenties and thirties (if you will allow me to exaggerate just a 
little). Though many had impressive features, none contained the kind of unified picture of the world of language that we were looking for.

The sensible thing to do next, we believed, was to draw more heavily on what the Head of the House of Hearts had to offer. So we rounded up All The King's Horses. (For the record I may add that we did leave a few that were too wild to be roped in.) That is, we turned to the many, many technical texts in which the microtexture of the world of language is pictured in all its fine-grained splendour. We hoped, you see, that if we looked at some of these pictures in a mirror, we would get reflected, by a kind of magical inversion, an overall picture of this world's large-scale features. Though we marvelled at the reflection, at the detail in which many microscopic analyses revealed this world's finer fibres, our hopes were comprehensively dashed. What we saw was not a picture of the general architecture and dynamics of the world of language as a whole. Rather, the mirror cast back at us an inverted image of a highly fragmented world, a world analyzed to smithereens as it were. Mirror magic, clearly, was not going to solve our problem.

After much to-ing and fro-ing, it occurred to us to turn for inspiration to cosmologists, a fraternity of scholars eminently experienced at studying enormous places. Scientific cosmology, after all, had a goal very similar to ours: to portray the universe as a whole, showing its large-scale features and how they hang together. To get the job done, so we were told, observational astronomers and theoretical cosmologists worked together, the former gathering observational clues about the universe, and the latter piecing them together and interpreting them in revealing ways.

The instruments of observational astronomers, unfortunately, are of no use to linguists. The world of language is largely hidden even from the technologized eye. No instrument or sense organ, however souped up, can tell us much about this world. We have to 'look for' our basic data in a different way. And this is where the more highly 
bred of The King's Horses come in handy. Microscopic analyses of the world of language may not provide us with readily invertible pictures of its large-scale features. What they do offer us, however, are microlinguistic clues to these features. By using these clues in the right way, we can make claims about the large-scale features of the world of language that are firmly, if indirectly, grounded in empirical fact.

The microlinguistic clues in question have to be properly interpreted, of course, just as astronomical observations have to be interpreted by theoretical cosmologists. It is only by interpreting the clues that theoretical cosmologists can hope to come up with a picture of the universe as a whole. The pictures they draw of the universe take the form of conceptual models. Conceptual modelling, the means by which the pictures are drawn, may be likened to a 'macroscope'. If you do not know what a macroscope is, imagine an instrument, the counterpart of a microscope, that enables the mind's eye to 'see' how the large-scale features of something really complex interlink to form the basic arclitecture and dynamics of the whole. And when linguists focus their macroscopes, even the systematic introductions to language produced by the pick of the King's Men can become useful, identifying, as they do, some of the main traits of the world of language.

It is one thing to have a fair idea of what a macroscope can show you. Trying one's hand at twiddling its knobs, though, is a different matter altogether. Which means that the macroscopic picture of the world of language that we have been working on is bound to be blurred in some areas and wrong in others. Cosmologists know from experience that macroscopic pictures of big places are never accurate the first time round. It is this knowledge that prompted John Wheeler, a famous member of their fraternity, to declare: 'Our whole problem is to make the mistakes as fast as possible' (quoted by Karl Popper in THES, 24 July 1992, p. 15). This, in essence, is our 'whole problem' too. 
Accuracy, elusive as it may be, is not our only goal, however. A picture of the world of language also needs to be painted in a style that will tempt linguists and other scholars to take a fresh look at a world with which they may feel quite familiar. A canvas covered with conventional cosmological cant most certainly will not achieve this. ${ }^{1}$ That is why we have involved in our project Lewis Carroll, a past master at painting new worlds in a delightfully refreshing way. ${ }^{2}$ And, as a back-up, we have Carroll's latter-day understudy, Gilbert Adair. ${ }^{3}$

So, the lot having fallen to me to produce a first version of the picture in question (and, no doubt, to make the mistakes as fast as possible), I am offering you this preview. I will rely on you to point out to me where my macroscopic picture of the world of language is divorced from reality. And where the brushwork could be more Carrollinian. 


\section{INTRODUCTION: A GRAND SURVEY}

'Of course the first thing to do was to make a grand survey of the country she [i.e., Alice] was going to travel through' [TLG 215]

What do you make of a world in which people can shut up or open out like telescopes by taking mysterious substances? Or of one in which it takes all the running that you can do to stay in the same place? The former world, of course, is that of Wonderland, into which Alice tumbled when she fell down a rabbit-hole. The latter one she entered through a looking glass. Of the many famous make-believe worlds, few, if any, are so crammed with enchanting phenomena as those visited by Alice.

But truth is stranger than fiction, as the saying goes. And, indeed, there are real worlds that are even more intriguing than the dream-worlds created by Lewis Carroll. The world of human language is such a world. Real people can acquire languages without consciously learning them. They can be endlessly creative in their use of the languages they know. They can mean something totally different from what they are actually saying, and yet be fully understood. They can create new languages almost overnight, should a highly pressing need arise. And so on, and so forth.

Even more fascinating, however, are the intricate mechanisms that give rise to these phenomena. On this score Wonderland and Looking Glass Country are no match for the real world of language. A little girl growing in a wink to be two miles high, a caterpillar with folded arms smoking a long hookah, a baby turning into a pig, and a cat that disappears, leaving only its smile behind, engrossing as they may be, are quite shallow phenomena. That is, they are not products of the workings of hidden mechanisms --- of invisible things, processes, and so on --- which would allow one to make sense of them in a systematic way. 
The hidden mechanisms, in turn, are as they are and work as they work because the world of language has as a whole certain large-scale features. These features determine the general architecture and dynamics of this world. To fully understand the world of language one, ultimately, has to come to grips with this architecture and dynamics. The aim of what follows is to present a conceptual model of the large-scale features that characterize the world of language as a whole.

Finding your bearings in a new world can be an unsettling business. This Alice discovered soon enough in Looking Glass Country where, in order to get to a place, she had to walk away from it. And where she found, to her amazement, that people lived backwards in time, remembering best the things that happened the week after next. Indeed, there is a lot to say for not entering new territory by tumbling head over heels into it! So it will be worth our while to check our descent into the world of language temporarily in order to survey its large-scale features from a distance. This will be easier, however, if we first settle a point of terminology.

I have used the expression 'the world of language' as a sort of terminological crutch to get us this far. (Though the idea of using a crutch for falling down a hole may smack of Carrollinian paradox!). But the expression is somewhat unwieldy, as crutches often are. So, in most contexts, we will henceforth use the less wordy expression 'linguistic reality' as a synonym for 'the world of language'. The term reality in plain language means 'all the things that exist'.

What, then, are the large-scale or macro(scopic) features that characterize linguistic reality, collectively determining its general architecture and dynamics? In subsequent sections, the following macrofeatures will be examined: 
(F1) Linguistic reality is (multi-)layered. The four basic layers of linguistic reality are those comprising language products, language behaviour, language capacities, and language itself.

(F2) Linguistic reality is (multi-)dimensional. Fundamental amongst the dimensions of linguistic reality are those of function, structure, use, diversity, phylogeny, ontogeny, and physical bases.

(F3) Linguistic reality is (poly-)systemic. For example, a person's faculty for language consists of two basic systems: the capacity for (acquiring) language and the (acquired) knowledge of language. Knowledge of language, in turn, is made up of such subsystems as grammatical competence, pragmatic competence and a conceptual system.

(F4) Linguistic reality is (multi-)domainal. The domains to which linguistic things and processes belong include the material, the mental/biological, the social, the abstract and the artifactual.

(F5) Linguistic reality is dynamic. Various kinds of events, processes, changes, and so on constantly occur within this reality.

(F6) Linguistic reality is (multiply-)interconnected. The various components of linguistic reality are interlinked in specific ways; as a whole, linguistic reality is in turn interconnected with other, nonlinguistic, realities.

(F7) Linguistic reality is lawful. It is governed by various kinds of laws, principles, constraints, rules, norms and so on. 
The first four features, (F1)-(F4), reflect the major ways in which linguistic reality is structured; the final three features, (F5)-(F7), reflect pervasive properties of much of what this reality contains.

In exploring each of the large-scale features of linguistic reality, we will be guided by three main questions:

(Q1) How is the feature concretely manifested or instantiated by specific linguistic things, processes, and so on?

(Q2) What is the general nature of the feature?

(Q3) How is this feature interlinked with others?

These questions sound a lot more straightforward than the Mad Hatter's famous riddle 'Why is a raven like a writing-desk?' but good answers are not there for the picking: linguistic reality is a vast and complex domain which has not been staked out systematically from a macroscopic perspective. As mentioned in the Preface, though, there is fortunately a variety of studies of the microtexture of linguistic reality that yield clues about its large-scale features. As clues go, however, these don't wear their meaning on their sleeves. Interpreting these microlinguistic clues just is no simple matter. Which means that the answers to questions (Q1)-(Q2) will necessarily be restricted in scope and depth. And, above all, that these answers cannot but be tentative. Nevertheless, it will become clear that linguists can deal with these questions in an insightful way on the basis of microlinguistic clues. Indeed, linguists are much better off than the Hatter and his companions, who were completely nonplussed by the 'raven' riddle: 
"Have you guessed the riddle yet?" the Hatter said, tuming to Alice again. "No, I give it up," Alice replied. "What's the answer?" "I haven't the slightest idea", said the Hatter. "Nor I," said the March Hare.

Alice sighed wearily. "I think you might do something better with the time," she said, "than wasting it in asking riddles that have no answers."' [AIW 97]

Which brings us to how this study is organized. Focussing in turn on each of the layers mentioned in (FI) and on their basic ingredients, Part 1 tries to build a model of its bare bones. This skeleton is fleshed out in Part II, where linguistic reality is looked at from six complementary perspectives: those identified in (F2)-(F7) above as dimensions, systems, domains, dynamicism, interconnectedness and lawfulness respectively. 


\section{PART I}

\section{LAYERS : FROM CRUST TO CORE}

'Down, down, down. Would the fall [down the rabbithole] never come to an end? "I wonder how many miles I've fallen by this time?" [Alice] said aloud. I must be getting somewhere near the centre of the earth.' [AIW 27]

Can you imagine a kind of world that is all surface with nothing underneath? Not even Lewis Carroll tried his hand, or rather imagination, at conjuring up such a place. Building a conceptual model of linguistic reality, fortunately, does not require such mental acrobatics. A first large-scale feature of linguistic reality is that it is made up of various layers. In this part of our study we will first go over the four main layers of this reality: those of language products, language behaviour, language capacities, and language itself. After that we will consider, from a more abstract point of view, the idea of a 'linguistic layer', the grounds for distinguishing one layer from another, and the nature of the links between adjoining layers. 


\section{Language products}

Consider an exchange between Alice and the Hatter about his curious watch:

... 'Does your watch tell you what year it is?' [asked the Hatter.]

'Of course not,' Alice replied very readily: 'but that's because it stays the same year for such a long time together.'

'Which is just the case with mine,' said the Hatter.

Alice felt dreadfully puzzled. The Hatter's remark seemed to her to have no sort of meaning in it, and yet, it was certainly English.' [AIW 96-97]

This passage by Lewis Carroll is made up of written utterances. Some of these he uses to represent, in writing, utterances spoken by Alice or the Hatter. Others he uses to describe Alice's judgements about some of the Hatter's utterances or about the meaning of those utterances. Alice judges, for instance, that the Hatter's utterance Which is just the case with mine has no meaning but is certainly (good) English. The quoted passage furnishes examples, in fact, of the two basic kinds of ingredients of the surface layer of linguistic reality: utterances and people's judgements about utterances. But let's look at the two kinds of ingredients in turn.

\subsection{Linguistic utterances}

Utterances --- or linguistic utterances --- are what people produce by speaking, writing, and signing. Here are some more examples of utterances (they will be used a little later to illustrate some general points): 
1a Alice sighed out of frustration.

b The Gnat sighed itself out of existence.

c The Gnat sighed itself.

d The Gnat sighed existence.

2a The Cat vanished, leaving its grin behind.

b The Cat, leaving behind its grin, vanished.

c The Rat vanished, leaving its gin behind.

d Vanished, the Cat licked up its grin.

3a Have you pricked your finger?

b I haven't pricked it yet.

c I haven't licked it yet.

d Fingers are for flicking, toes for clicking!

4a Were you ever punished, Alice?

b Do you insist on an answer, your Majesty?

c It is none of the business of a nosey old witch!

We will take it that an utterance is a product of a bit of action by someone, and not the bit of action itself. In doing so, we will not follow scholars who have used the term utterance in an ambiguous way to denote both products and bits of action or acts. ${ }^{1}$ But let us inspect utterances a little closer, focusing first on their signal and then on their meaning.

\subsubsection{Utterance signals}

An utterance has an observable aspect, a signal, which is produced by means of speaking, writing or signing. The signal of a spoken utterance is phonic in substance: 
it is a stretch of speech sound preceded and followed by silences. Stretches of speech sound exist fleetingly as disturbances or vibrations in the air that can be heard by humans. ${ }^{2}$ The sound of spoken utterances is produced by people in the vocal tract, a system of three hollow areas or cavities: the nose, the mouth and the pharynx (that is, the part of the throat above the voice box). Not all the kinds of sound that can be produced in the vocal tract, however, are (normally) used for realizing spoken utterances. These include the kinds made by Alice sucking in her breath in surprise, by the White King nervously clearing his throat, by the Duchess's baby alternately sneezing and howling (without a moment's pause), and by the scared Knave's teeth chattering uncontrollably. Speech sound clearly does not equal vocal tract sound.

But let us turn to the silences flanking the signals of utterances. The nature of these silences can be easily misunderstood, as is illustrated by a particular exchange in the dream world created by Gilbert Adair beyond the needle's eye. It started with Jill - who was still in the foul mood caused by her tumble down the hill - screaming at Alice:

'Heard one [silence], heard them all! This new silence of yours is exactly the same - word for word, I swear - as the last!' [TNE 95]

And it continued with Alice protesting rather confusedly:

'The words I spoke - I mean, that I didn't speak - during this silence were quite different from those of the silence before.' [TNE 95]

Though sounding a bit more coherent than Alice, Jill nevertheless had it all wrong. To see why, let us dwell for a moment on the nature of the kind of silences about which Alice and Jill were at odds with each other. 
At first blush, silence seems to be no more than a kind of nothingness: the absence of sound. But the linguistic silences --- also called pauses --- that precede, interrupt or follow utterances are very real things indeed in terms of what they can do. By putting linguistic silences or pauses in their speech people can 'punctuate' it, in fact, thus organizing their verbal interaction or conversation in certain ways. A silence, for example, can signal a point in a conversation at which someone who has not been speaking can get a turn at doing so. People can use silences, moreover, to 'say' or mean a variety of things. For example, by remaining silent or pausing, one can 'say' such things as 'You have me in a corner there', 'What you say is completely ridiculous', 'I won't cooperate with you', 'I refuse your request', 'I have to agree with you on that', 'I am now threatening you', 'I am now being respectful', and so on. Interestingly, in different 'languages' or cultures, the 'same' silence can mean different things. For example, if a woman kept silent in response to a question like 'Will you marry me' then she would be saying 'Yes' in Japanese, 'No' in Igbo, and 'I' $m$ not sure' in English. So, Jill's sentiments notwithstanding, linguistic silences or pauses are important linguistic things, a distinct kind of ingredient of the most directly given layer of linguistic reality. ${ }^{3}$

The signal of written utterances is graphic in nature, existing as marks on some kind of surface. The marks are typically deposits of some sort of stuff: ink, carbon, graphite, and so on. And the kinds of surfaces vary widely as the following curious Carrollinian finger-posts show:

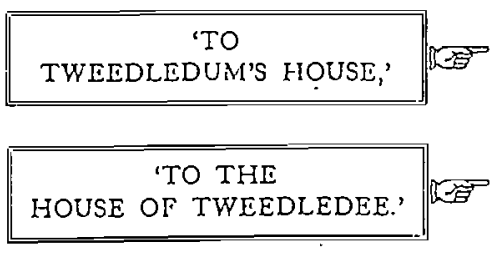


As very young children learn to their frustration, not just any series of scratches or scrawls will count as a written signal. Only conventional arrangements of marks drawn from writing systems and other systems of graphic expression will pass the test. ${ }^{4}$

As produced in a natural way by the deaf, the signals of signed utterances are visible too. Also called signs, such utterance signals consist of hand configurations and hand movements made by signers at a place on or in a space near the upper part of the body. The signs produced in this way are generally accompanied by modulating movements of the signer's shoulders, head, lips and/or brows. The make-up of signs is governed by the conventions or rules of a sign language --- British Sign Language, American Sign Language and Chinese Sign Language being typical examples. ${ }^{5}$ The following utterance in American Sign Language gives a rough idea of how such signs look:

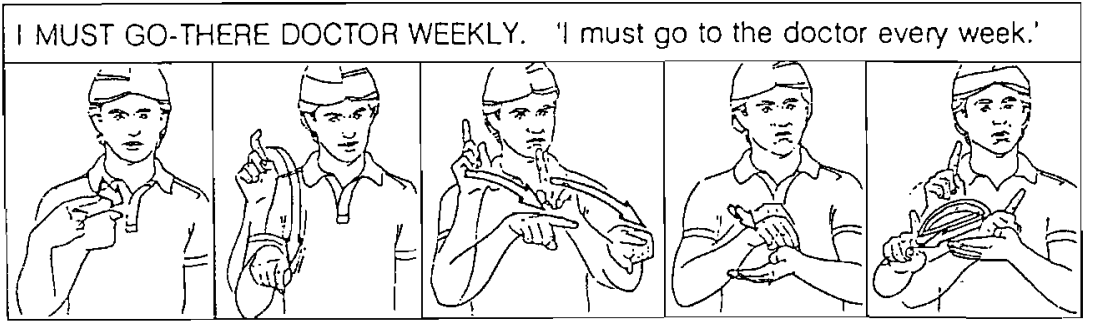

But imagine now the Cat winking conspiratorially at Alice, the Duchess clicking her fingers to summon the Cook, the Knave of Hearts clasping his hands to beg the Queen's mercy, Tweedledum angrily shaking his fist at Tweedledee. Are these characters producing signs in a Carrollinian Sign Language? No, they are not making signs but rather gestures of a conventional sort. Such gestures are indeed used to communicate a limited number of basic ideas, feelings, desires and so on. But they are used in a far less systematic and comprehensive way than signs are. Though some gestures have acquired a fixed meaning in certain cultures, the use of gestures is not governed by a system of conventions or rules comparable to a sign language. Unlike 
signs, gestures are not considered to be (the signals of) linguistic utterances and are not ingredients of linguistic reality. Nevertheless, gestures play an important role in the communicative behaviour of people, a point that will be fleshed out in par. below. ${ }^{6}$

In considering the nature of utterance signals and in distinguishing among spoken, written and signed utterances, I have skirted various difficulties that are not relevant to our present concerns. ${ }^{7}$ There is one distinction, however, that is important to a macroscopic picture of linguistic reality: the distinction between utterances and sentences. To see what this distinction is about, let us look at a bit of distinctly unregal behaviour in which the Queen of Hearts indulged during a curious game of croquet played in Wonderland. The game was a chaotic affair with live hedgehogs serving as balls and flamingoes doing duty as mallets, whilst soldiers stood on their hands and feet to make the arches. The unruly conduct of the players --- all playing at once, quarreling all the while --- was too much for the Queen, a bloodthirsty soul if ever there was one:

'... in a very short time the Queen was in a furious passion, and went stamping about, and shouting "Off with his head!" or "Off with her head!" about once a minute.' [ATW 112]

Suppose that the murderous monarch shouted twenty-five times in all 'Off with his head!'. Suppose, that is, that she produced twenty-five utterances that can be represented as 'Off with his head!'. The signals of no two of these utterances would have been identical. Each would have been unique in regard to such acoustic properties as pitch, quality, intensity, and duration. This we know from experimental phonetic investigation of speech. Each of the utterances could, moreover, have referred to a different candidate for beheading. But, despite such differences, Alice and her companions would have intuitively judged the twenty-five utterances to be 'the same'. 
How is one to reconcile this judgement of sameness and the existence of the differences listed above? To do just this, various linguists have adopted a distinction between utterances and sentences. And they have assumed that one and the same sentence can be realized by various utterances that differ from one another in regard to properties such as those mentioned above. Returning to the hard-hearted Queen of Hearts, these linguists would say that she uttered one and the same sentence twenty-five times and that, in doing so, she produced twenty-five unique utterances of it. ${ }^{8}$

Unlike utterances, sentences are not considered to be stretches of speech sound, strings of (written) marks on surfaces or series of hand-movements. Sentences, rather, are taken to be nonphysical entities that can be uttered or physically realized more than

once. And because they are not directly given, sentences do not form part of the outward layer of linguistic reality. As we proceed, we will see that leading linguists hold different opinions on exactly what kind of nonphysical things sentences are and on where exactly sentences fit into linguistic reality. Some leading linguists, it will become clear, do not consider sentences to be real components of the world of language at all.

\subsubsection{Utterance meanings}

Faced with the Hatter's question 'Does your watch tell you what year it is?', Alice tried to do the normal thing: to figure out its meaning. And she succeeded in this, as is clear from her reply 'Of course not ... but that's because it stays the same year for such a long time.' The meanings that people assign to utterance signals they hear or see form a second kind of ingredient of the most directly given layer of linguistic reality. Such utterance meanings result, in other words, from something that people do; so, in terms of origin, they too are products. 
But what is the nature of the meanings people assign to utterances they hear or see? Fortunately, this is not a question about the nature of meaning in general. Meaning in general, you see, is a notoriously slippery sort of stuff, as was gravely pointed out to Alice by Gilbert Adair's Grampus, an elderly whale-like creature clad in a dusty black professor's gown and mortar-board:

'Meaning, my dear, is a rare and precious substance... so precious that, if my opinion were asked bout it, it [i.e.; meaning, R.P.B.] should be preserved under a bell jar in the Museum - on view to the Public, Tuesdays and Fridays at sixpence a time.' [TNE 79]

The Grampus, of course, echoes a sentiment of many a linguist and philosopher. So let us rather focus on the nature of the meanings assigned by people to specific utterance signals, meanings so ordinary and plentiful that no museum curator would dream of putting specimens of them on display.

The meaning of a specific utterance is conventionally taken to be the information conveyed by its signal. A variety of factors are taken to contribute to this information. The first is the inherent meaning of the sentence that was uttered. (Recall in this connection the distinction drawn above between an abstract sentence and the concrete utterances resulting from its use.) The meaning of a sentence, in turn, is determined by the meanings of its individual words and by the ways in which these words are interlinked. A couple of examples will help to clarify this point.

Shouted by the Queen to the Executioner, the utterance Off with her head! roughly means 'I order you to behead a certain female'. Suppose, however, that in a less murderous mood the Queen, using her to refer to Alice, uttered $5 \mathrm{~b}$ or $5 \mathrm{c}$. 
5a Off with her head!

b Off with her hair!

c Head her off?

The sentence uttered as $5 \mathrm{~b}$ differs from the one uttered as $5 \mathrm{a}$ in regard to only one word. Yet, the two utterances differ considerably in meaning, as Alice - given the choice between being beheaded and being subjected to an obligatory haircut - would surely have agreed to her relief. This dramatically illustrates the contribution made by the meaning of individual words to the meaning of an utterance. And if the Queen had said $5 c$ rather than $5 a$ or $5 b$, Alice would have been even better off. For $5 c$ roughly means that someone (the Executioner) must cause a certain female (Alice) to change the direction in which she has been moving. There is obviously a vast difference in meaning between $5 \mathrm{a}$ (or $5 \mathrm{~b}$ for that matter) on the one hand and $5 \mathrm{c}$ on the other hand. And this difference is not due to the fact that whereas $5 \mathrm{a}$ contains the word with, $5 \mathrm{c}$ does not. Rather, this difference in meaning is due to the fact that the words head, her and off are interlinked in $5 \mathrm{c}$ in a way quite unlike that in which the words off, with, her and head are interlinked in 5a. This is to say that (the sentences uttered as) $5 \mathrm{a}$ and $5 \mathrm{c}$ differ greatly in regard to form or structure. By contrast, (the sentences uttered as) $5 \mathrm{a}$ and $5 \mathrm{~b}$ have the same form or structure. The form or structure of a sentence is the way its words hang together, to oversimplify a rather complex idea.

The meaning of the utterances that precede and/or follow an utterance is the second factor that may contribute to the meaning of this utterance. Together, such surrounding utterances form the linguistic context or the co-text of the utterance. Suppose the Queen shrieked Off with her head! immediately after she had said 6.

6 I can't stand Alice's stupid questions any longer. 
Uttered in the context of 6 , Off with her head! conveys information differing in an important way from the information it conveys when spoken immediately after 7 .

7 I can't eat the Cook's awful food any longer.

Clearly, the information conveyed by her differs significantly between the two contexts.

The third factor contributing to the meaning of an utterance comprises the features of the non-linguistic context in which it is produced. These include the time when, the place where, and the occasion on which the utterance is produced, the identity of the speaker and the addressee, the knowledge shared by them about the world, including one another, and so on. Suppose, for example, the Executioner knew the Queen to be a rash person given to overstatement. He would not then understand the Queen's utterance of Off with her head! as ordering him to literally cut off someone's head. He would simply take it as an exaggerated expression of irritation by a person in a foul mood. By contrast, if Off with her head! were uttered by a cold-blooded monarch with a reputation for having dissident subjects beheaded as a matter of course, this utterance would have the Executioner sharpening his axe.

This brings us to the fourth factor contributing to the meaning of an utterance: the nature of the speech act performed - that is, the nature of what is done linguistically by the person producing the utterance. For example, by producing an utterance, someone may make a statement, ask a question, express a request, give an order, make a promise, express an apology, utter a blessing or a curse, and so on. Suppose that off with her head! were not produced by the enraged Queen. Suppose, rather, that the Executioner uttered it and that in doing so he said it with a rising intonation, i.e. with his voice going up toward its end. In writing, this utterance is represented as follows: 
Spoken with a rising intonation, the utterance clearly does not mean 'I order you to behead a certain female'. Rather, the Executioner could be asking a question which means roughly 'Am I correct in understanding that you wish a certain female to be beheaded by me?'. Or, the Executioner could be making a statement conveying the information 'You must be mad/joking/..... to wish a certain female to be beheaded by me'. The meaning of an utterance, clearly, depends in part on the nature of the speech act performed by the person producing it.

The meaning of an utterance, then, is the information conveyed by it. When we consider the purposes of language behaviour in par. 2.2.1 below, it will become clear that this information may belong to different kinds. For now, it is sufficient to note that the nature of the meaning of specific utterances is much less mysterious than the nature of meaning in general. Which, of course, is not to say that it will be easy to state what every specific utterance means. The Grampus, however, pushes the point a bit too far when he laments that 'the best meanings ca'n't ever be written down'. [TNE 80]

\subsection{Linguistic judgements}

Recall that Alice judged The Hatter's utterance 'Which is just the case with mine' 'to have no sort of meaning in it' though 'it was certainly English'. Such judgements form a second kind of ingredient of the crust of linguistic reality. But what, in essence, are judgements of this sort? To get a grip on this question, we have to look at more examples, calling them 'linguistic judgements' from now on. So let us go back to the utterances in (1)-(4) above. Someone who knows English may judge, for example, that (1a) is 'normal English'; that (1b) 'says something funny' but is 'good English' too; that (1c) and (1d) are 'not (good) English'. Tuming to the utterances (2a)-(2d), 
someone may judge that (2a) and (2b) 'look rather different' but 'mean the same thing'; that (2a) and (2b) mean that the ('left-behind') grin cannot be that of anything/one else but the Cat; that (2c) 'looks a lot like' (2a) but 'has a different meaning': and that (2d) 'makes no sense at all'. As for the utterances (3a)-(3d), someone may judge that (3b) is a 'proper reply' to question (3a), but that (3c) isn't; that (3d), despite being 'good English', 'is not an (appropriate) answer' to (3a); and that (3d) is a 'loony response' to (3a). Which brings us to (4a)-(4c): as a reply to the question of (4a), (4b) could be judged to have 'the right, respectful tone'; the one given in (4c), by contrast, could be considered 'not the proper way for a young girl to talk to a queen'.

Linguistic judgements such as the above express opinions that people have about the ways in which utterances of their language are formed, understood or used. Many such judgements simply say that particular utterances are considered to be good or bad, identical or distinct, similar or different and so on in regard to form, meaning or use. This characterization of linguistic judgements, obviously, requires some fleshing out. So let us reflect for a moment on the following questions: In what are linguistic judgements rooted? What makes judgements linguistic?

As for the first question, people normally cannot give the real grounds for linguistic judgements such as the ones considered above. For example, they are normally unable to say why they judge an utterance such as The gnat sighed existence to be 'bad' or 'not English'. People make such linguistic judgements in a wink without recourse to reasoning or without using their senses. Judgements whose bases cannot be given are considered to express intuitions. Linguistic judgements of the sort considered above have accordingly also been called linguistic intuitions. ${ }^{10}$

To call a particular linguistic judgement 'intuitive' is not to say that it is necessarily correct: the linguistic intuitions expressed by such judgements are not by their very 
nature infallible. Nor are linguistic intuitions invariable: not all the people speaking the same language will have the same intuitions about 'the same' utterances. This holds even for some inhabitants of Looking-Glass Country, where Alice judged an old Frog's utterances to be in less then good order --- much to the dismay of the Frog, who insisted:

'I speaks English, doesn't I?' [TLG 328]

On different occasions, moreover, one and the same person may make conflicting judgements about 'the same' utterance, first judging it, for example, to be 'bad English' and later to be 'good English'. Here, we are not yet ready to explore the reasons why intuitive linguistic judgements can be false or why they can vary. ${ }^{11}$

What, then, makes the intuitive judgements which we have been looking at linguistic judgements? Alice often judged things said to her by her companions hard to believe, difficult to fathom, nonsensical, and the like. Consider, in this connection, the following utterances spoken by the White Queen, the White King and the Unicom, respectively.

9a I'm just one hundred and one, five months and a day. [TL $G$ 251]

b To be able to see Nobody! And at that distance too. Why it's as much as I can do to see real people by this light! [TLG 279]

c Hand it [ = a looking-glass cake] round first, and cut it afterwards. [TLG 290]

Alice judged 9a quite hard to believe, $9 \mathrm{~b}$ difficult to fathom, and $9 \mathrm{c}$ nonsensical. There are linguists, however, who will not see these judgements by Alice as linguistic 
judgements. In support of this view, they will argue that linguistic judgements have to be judgements about linguistic properties of utterances. And that neither credibility, nor the truth nor the sensicality of what anyone says represents a linguistic property of the utterances in question.

Which brings us to a general point: not every judgement made intuitively in response to a given utterance represents a linguistic judgement about the utterance. Whether judgements about utterances do or do not constitute linguistic judgements about these utterances depends on certain assumptions made by linguists. These include assumptions about what are and what are not linguistic properties of utterances. These assumptions, in turn, reflect beliefs about the nature of the entities --- such as language and languages --- that form part of deeper layers of linguistic reality. Since linguists disagree about these beliefs, they also disagree about what the linguistic properties of utterances are. For example, many linguists agree that 'being good/well-formed', 'sounding different from', 'rhyming with', 'differing in meaning from', 'having the same meaning as', 'having more than one meaning' are indeed linguistic properties of utterances. But there is disagreement among linguists about such properties as 'being (necessarily) true', 'making sense' and so on. ${ }^{12}$

\subsection{Texts and discourses}

Linguistic utterances and linguistic judgements, then, are the basic ingredients of the outer layer of linguistic reality. But are they the only ingredients of this layer? To go into this question a little, let's consider the following four utterances: 
10a The Cat vanished, leaving its grin behind.

b In Dreamland, you see, grins can fade but not disappear.

c This suited the Sad Hatter, who had long ago forgotten how to smile.

d He deftly sewed the faceless grin on to his hat, muttering absentmindedly, 'Down with grinning cats, up with grinning hats'.

Taken together, these utterances differ in an important way from the four listed as 2a-d. The four utterances $10 \mathrm{a}-\mathrm{d}$ are linked to each other in such a way that they form a cohesive collection or, as it is conventionally called, a text. (Taken together, these utterances may even form a fragment of an Alice story never published by Lewis Carroll!) The cohesive nature of this collection of utterances is reflected, for example, by the fact that for the meaning of This in $10 \mathrm{c}$ one has to 'go back' to $10 \mathrm{~b}$ and for the meaning of he in $10 \mathrm{~d}$ one has to 'go back' to $10 \mathrm{c}$.

The four utterances $2 a-d$, by contrast, are not linked to each other in a similarly cohesive way. In the absence of such cohesion, these utterances consequently do not form a text. As a collection, $2 \mathrm{a}-\mathrm{d}$ does not represent a whole that is more than the sum of the individual utterances.

The general point is that, along with utterances and judgements, the outer layer of linguistic reality also contains texts. Made up of utterances, however, texts are compound or nonbasic ingredients of this layer. The utterances making up a text may be either written or spoken ones. To distinguish terminologically between spoken texts and written texts, linguists often refer to spoken ones as discourses. ${ }^{13}$ 


\subsection{Crusthood}

And so we have passed through the crust of linguistic reality, its surface or outermost layer. The basic ingredients of the layer of language products, we have seen, are utterances - characterized by a signal and a meaning - and intuitive linguistic judgements. In addition, the outward layer contains cohesive collections of utterances, texts and discourses to be specific. You may have been wondering why this layer has been pictured as the 'outward' or 'surface' layer. Not because its ingredients are observable: utterance meanings and intuitive judgements are not. The answer is rather that this is the most directly given layer in the sense that one can get to its ingredients without having first to penetrate some other layer of linguistic entities.

It has to be borne in mind, though, that to be able to identify the utterances of a particular language as distinct from nonlinguistic noises, ink scrawls or hand movements, one has to know the language. This point is illustrated in a rather striking way by an experience of one Reverend Farrar who lived nearly a century ago. Not knowing the language of the Yamparico all that well, he found it quite difficult to distinguish their speech from 'the growling of a dog'. ${ }^{14}$ This goes to show that even the most directly observable kind of ingredients of the crust of linguistic reality cannot be recognized for what they are by just anyone who has ears to hear and eyes to see. 


\section{Notes to Preface}

1. Consider, for example, the following passage:

'This is a study in linguistic ontology. Ontology, as practised by Bunge and others, is a science that systematically and clearly stakes out the main traits of the real world as known through science. To achieve this, ontologists have to recognize, analyze and interrelate those concepts that will enable them to produce a unified picture of reality, reality being the aggregation of all those things of which there are nondenumerably many.

Linguistic ontology is concerned with linguistic reality or, more precisely, the linguistic domain of reality. Like other domains of reality, linguistic reality consists of things that are in flux, i.e. things undergoing change. Things represent propertied individuals and changes are events or processes.

Linguistic cosmology is the branch of linguistic ontology that builds conceptual models of the large-scale features that linguistic reality has as a whole. These features include .....'

This passage illustrates the style and idiom in which ontological/cosmological texts are standardly written: it is based on Mario Bunge's work Treatise on Basic Philosophy. Volume 3. Ontology I: The Furniture of the World (Dordrecht and Boston: Reidel. 1977.). While metascientists, most likely, will digest such a passage as normal fare, ordinary linguists, having no stomach for what they consider meta-stuff, most definitely won't.

2. The two Carroll stories that will figure prominently in my account are Alice's Adventures in Wonderland [also to be referred to as $A I W$ ] and Through the Looking-Glass and What Alice Found There [also to be referred to as TLG]. Except where otherwise indicated, these references will be to The Annotated Alice, Penguin Books, 1965.

3. In addition to drawing on the two Alice stories written by Lewis Carroll, I will make use of Gilbert Adair's Alice Through the Needle's Eye [also to be referred to as TNE] (London: Macmillan. 1984). 


\section{Notes to Chapter 1}

1 For this terminological distinction see Lyons 1977:26.

2 For a review of some of the problems that make it difficult to give a rigorous characterization of the nature of utterances (as products) see, for example, Lyons 1968:171-172, 1981b:23-26.

3 For some discussion of the properties and functions of (various types of) linguistic silences see, for example, Crystal 1987:172, Levelt 1989:35-37, 126128, Wardhaugh 1992:237-241, Poyatos 1993:135-137 and the literature reviewed in these sources.

4 For some discussion of the nature of speaking and writing see par. 2.3.2.

5 For some discussion of the properties of signed utterances see, for example, Crystal 1987:220-225, Padden 1988, Siple 1982, Sandler 1993, and the contributions to Fischer and Siple (eds.) 1990. We will return to the nature of sign languages in par. 4 below.

6 For some discussion of the properties and functions of such gestures see, for example, Crystal 1987:402-403, and Graddol, Cheshire and Swan 1987:135137.

7 For some discussion of the relation between written and spoken utterances see, for example, Olson 1993 and the literature reviewed there. We will return to the relation between speaking and writing in par. 2.3.2 below. 
For some discussion of the distinction between utterances as physical entities and sentences as nonphysical entities, see, for example, Lyons 1981b:23-26, Burton-Roberts 1985, Allan 1986:55-58, Bromberger 1989, Carr 1990:43-44, and Katz and Postal 1991:522-523. Various linguists --- for example, Lyons 1977:13-18 and Katz and Postal 1991:522-523 -.- invoke the distinction drawn by Peirce (1933, Part IV:423-424) between types and tokens as the basis for their distinction between utterances and sentences. In terms of Peirce's distinction, a type is a significant form that does not exist but that determines things that do exist. A token results from the use of a type and is a sign of the type. A token, moreover, is something 'Single': '[a] Single event which happens once and whose identity is limited to one happening or a Single object or thing which is in some single place at any one instant of time, such event or thing being significant only as occurring just when and where it does, such as this or that word on a single line of a single page of a single copy of a book ...' (Peirce 1933, Part IV:423).

9 For the nature of the meaning of utterances (or utterance-meaning) and the way in which it is related to the meaning of sentences (or sentence-meaning) see, for example, Lyons 1977:33ff., 1981a:163ff., 1981b:28, 171ff. For a survey of altemative conventional conceptions of what meaning is see Allan 1986:75ff.

10 For a discussion of the nature of linguistic intuitions see, for example, Botha 1968:69ff. To the question of how people make intuitive judgements of utterances we will return in par. 2.3.1.3 below.

11 For some discussion of these questions see, for example Botha 1973:173ff., 1981:57ff., $227 \mathrm{ff}$. and the references fumished there. 
12 For recent discussions bearing on this point see, for example, Botha 1992:132137, Fodor 1985:147ff., Katz and Postal 1991.

13 For some discussion of general properties of texts and discourses see, for example, Lyons 1981b:195ff., Brown and Yule 1983, Levinson 1983, Prince 1988. Both text and discourse are used in a number of different senses. Here we will note just one source of possible confusion. Like utterance, both text and discourse are used ambiguously in a product sense and/or an action or process sense. Above, these terms are used to denote cohesive collections of utterances as products, not the (bits of) action or processes by means of which the collections of utterances are produced. For this product vs. process distinction see, for example, Brown and Yule 1983:23-25. For some discussion of the nature of the ways in which utterances have to be interlinked to form a cohesive collection or text see, for example, Halliday and Hasan 1976, Brown and Yule 1983:190ff., and Traugott and Pratt 1980:31-24.

14 For Reverend Farrar's experiences see Mühlhäusler 1986:23. 


\section{Bibliography}

Allan, K. 1986. Linguistic Meaning. Vols. 1 and 2. London and New York: Routledge \& Kegan Paul.

Botha, R.P. 1968. The Function of the Lexicon in Transformational Generative Grammar. (Janua Linguarum, Series Maior 38.) The Hague: Mouton.

Botha, R.P. 1973. The Justification of Linguistic Hypotheses. A Study of Nondemonstrative Inference in Transformational Grammar. (Janua Linguarum, Series Maior 84.) The Hague: Mouton.

Botha, R.P. 1981. The Conduct of Linguistic Inquiry. A Systematic Introduction to the Methodology of Generative Grammar. (Janua Linguarum, Series Practica 157.) The Hague: Mouton.

Botha, R.P. 1992. Twentieth Century Conceptions of Language. Mastering the Metaphysics Market. Oxford: Basil Blackwell.

Bromberger, S. 1989. Types and tokens in linguistics. In George (ed.) 1989:58-89.

Brown, G. and Yule, G. 1983. Discourse Analysis. Cambridge, etc.: Cambridge University Press.

Bunge, M. 1977. Treatise on Basic Philosophy. Volume 3. Ontology 1: The Furniture of the World. Dordrecht and Boston: Reidel.

Burton-Roberts, N.C. 1985. Utterance, relevance, and problems with text grammar. Australian Journal of Linguistics 5:285-296.

Carr, P. 1990. Linguistic Realities. An Autonomist Metatheory for the Generative Enterprise. Cambridge Studies in Linguistics 53. Cambridge: Cambridge University Press.

Crystal, D. 1987. The Cambridge Encyclopedia of Language. Cambridge, etc.: Cambridge University Press. 
Fischer, S.D. and Siple, P. (eds.) 1990. Theoretical Issues in Sign Language Research. Volume 1: Linguistics. Chicago and London: The University of Chicago Press.

Fodor, J.A. 1985a. Some notes on what linguistics is about. In Katz (ed.) 1985:146160.

George, A. (ed.) 1989. Reflections on Chomsky. Oxford: Basil Blackwell.

Graddol, D., Cheshire, J. and Swann, J. 1987. Describing Language. Milton Keynes and Philadelphia: Open University Press.

Halliday, M.A.K. and Hasan, R. 1985. Language, Context, and Text: Aspects of Language in a Social-semiotic Perspective. Victoria: Deakin University Press.

Katz, J.J. (ed.) 1985. The Philosophy of Linguistics. Oxford: Oxford University Press.

Katz, J.J. and Postal, P.M. 1991. Realism vs. conceptualism in linguistics. Linguistics and Philosophy 14:515-554.

Levelt, W.J.M. 1989. Speaking. From Intention to Articulation. Cambridge (Mass.) and London: MIT Press.

Levinson, S.C. 1983. Pragmatics. Cambridge: Cambridge University Press.

Lyons, J. 1968. Introduction to Theoretical Linguistics. Cambridge: Cambridge University Press.

Lyons, J. 1977. Semantics. Vols. 1 and 2. Cambridge, etc.: Cambridge University Press.

Lyons, J. 1981a. Language and Linguistics. An Introduction. Cambridge, etc.: Cambridge University Press.

Lyons, J. 1981b. Language, Meaning and Context. Bungay, Suffolk: Fontana.

Mühlhäusler, P. 1986. Pidgin and Creole Linguistics. Oxford: Basil Blackwell. 
Newmeyer, F.J. (ed.) 1988b. Linguistics: The Cambridge Survey. Volume II. Linguistic Theory: Extensions and Implications. Cambridge, etc.: Cambridge University Press.

Newmeyer, F.J. (ed.) 1988c. Linguistics: The Cambridge Survey. Volume III. Language: Psychological and Biological Aspects. Cambridge, etc.: Cambridge University Press.

Obler, L.K. and Menn, L. (eds.) 1982. Exceptional Language and Linguistics. New York, etc.: Academic Press.

Olson, D. 1993. How writing represents speech. Language \& Communication 13:1-17.

Padden, C.A. 1988. Grammatical theory and signed languages. In Newmeyer (ed.) 1988b:250-266.

Peirce, C.S. 1933. Collected Papers of Charles Sanders Peirce. Vols. III (Exact Logic) and IV (The Simplest Mathematics). Edited by C. Hartshome and P. Weiss. Cambridge, Mass.: The Belnap Press of Harvard University Press.

Poyatos, F. 1993. Paralanguage. A Linguistic and Interdisciplinary Approach to Interactive Speech and Sound. Amsterdam: John Benjamins Publishing Company.

Prince, E.F. 1988. Discourse analysis: a part of the study of linguistic competence. In Newmeyer (ed.) 1988b:164-182.

Sandler, W. 1993. Sign language and modularity. Lingua 89:315-351.

Siple, P. 1982. Signed language and linguistic theory. In Obler and Menn (eds.) 1982:313-338.

Traugott, E.C. and Pratt, M.L. 1980. Linguistics for Students of Literature. New York, etc.: Harcourt Brace Jovanovich, Inc.

Wardhaugh, R. 1992. An Introduction to Sociolinguistics. Second Edition. 
CONTENTS OF PREVIOUS ISSUES OF SPIL PLUS

SPIL PLUS 1 (1980)

Jeanne Maartens

Nuwe ontwikkelings binne Chomsky se teorie van kerngrammatika

SPIL PLUS 2 (1980)

Alta Oosthuizen

Leksikale basiskategorieē. Probleme vir die "working grammarian"

SPIL PLUS 3 (1980)

Jeanne Maartens

Afrikaanse Sintaksis: 'n evaluering

SPIL PLUS 4 (1981)

Walter Winckler

Aspekte van die taksonomiese taalkunde

SPIL PLUS 5 (1981)

FONOLOGIE, SEMANTIEK, TAALPOLITIEK：DRIE BESPREKINGS

R.P. Botha

Oor vrye kritiese meningswisseling en die skete van peripatete

J. Roux

Praktiese fonetiek vir taalstudente ..... : 'n Evaluering

C. le Roux en M. Sinclair

'n Kritiese beskouing van Inleiding tot die Semantiek

R.H. Pheiffer

Bedenkinge oor die politieke kader van Tuiste in eie taal

SPIL PLUS 6 (1982)

\section{REPLIEK EN KRITIEK}

J.C. Steyn

Bedenklike Bedenkinge: Pheiffer se Taalpolitiek

D.P. Wissing

Fonetiek vir Eerstejaars: 'n kort waardering

SPIL PLUS 7 (1982)

CHOMSKY IN DIE JARE TAGTIG

R.P. Botha

'n Roete deur die wêreld van Chomsky

W.K. Winckler

Rules and Representations: Lees maar ... Daar staan wel wat daar staan 


\section{SPIL PLUS 8 (1983)}

TAALWETENSKAP EN DIE STUDIE VAN LITERATUUR

Rudolf P. Botha

Wat kan Taalwetenskap die student van literatuur bied?

Arnold Blumer

Basiskonsepte vir die doseer van taal en literatuur in die konteks van 'n vreemde kultuur

Wilhelm Liebenberg

Die rol van die Taalwetenskap in die ontwikkeling van die

Literatuurwetenskap

Henning Snyman

Implikasie as taalverskynsel

Johan C. Thom en Pieter G.R. de Villiers

Die relevansie van 'n linguistiese benadering tot die analise van klassieke tekste

SPIL PLUS 9 (1984)

Hester Waher

Chomsky se teorie van 'government-binding'

SPIL PLUS 10 (1985)

\section{AFDELING I}

ALGEMENE PERSPEKTIEWE OP DIE NORMERING VAN TAALGEBRUIK

D.D. Joubert

'n Sosiologiese konsepsie van norme

J.C. Steyn

Algemene aspekte van taalnormering

V.N. Webb

Taalnorme en Afrikaans. 'n Geval van twyfel en vertwyfeling?

W.K. Winckler

Oor die taalwetenskaplike gronde van taalgebruiksnorme:

"important" of "importantly"?

R.P. Botha en M. Sinclair

Die negende gebod in taalgebruik

\section{AFDELING II}

PERSPEKTIEWE OP DIE PRAKTYK VAN DIE NORMERING VAN AFRIKAANS

E. Raidt

Historiese perspektief op die normering van Afrikaans

L.C. Eksteen

Die rol van die Akademie in die standaardisering van die Afrikaanse spelling 
D.C. Hauptfleisch

Taalnormering en woordeboeke: 'n Praktykgerigte perspektief

T.J.R. Botha

Normering in die Afrikaanse Radio- en Televisiediens

J. Picard

Die normering van Afrikaanse vakterminologie

J.S. Schutte

Die taalpraktisyn as kruispunt

D.W. le Roux

Die Staatstaaldiens: Funksies en invloed ten opsigte van die normering van taalgebruik

G. Kroes

Die doeltreffendheid van die Afrikaanse Woordelys en Spelreëls as handleiding en naslaanbron by die onderrig van Afrikaans op tersiêre vlak

J.P. Botha

Die normering van Afrikaanse taalgebruik soos bevefen in die skool en die universiteit

J.M. Marais

Taalnormering in die skool: 'n onderwyser se perspektief

J. Esterhuyse

Die dominasie van die Afrikaner-lewensbeskouing binne die

Afrikaanse spraakgemeenskap, soos gemanifesteer in taalhandboeke vir hoërskole

L.R. Heiberg

$392-416$

Taaldokters

A. Gardiner

$366-371$

Die Afrikaanse taaldokter en die Hippokratiese eed: implikasies vir die taalgebruiker

H. Snyman

Norme by literêre taalgebruik

C.J. Conradie

Die normering van Afrikaanse Bybeltaal

AFDELING 111

PERSPEKTIEWE OP DIE NORMERING VAN ANDER TALE

E. Loubser

$489-496$

Normering op die Nederlandse taalgebied

E. Ridge

$497-512$

Norms in British and South African English

S. Skorge

Norme en normkritiek ten opsigte van die Duitse taal:

'n kort oorsig 
P. Brink

Taalnormering in Frankryk

J.M. Lenake \& C.F. Swanepoel

$573-590$

Historiese aspekte van normering in Suid-Sotho

$591-604$

Taalgebruiksnormering in die Suid-Afrikaanse Bantoetale

\section{SPIL PLUS 11 (1987)}

Rudolf P. Botha

The generative garden game: challenging Chomsky at conceptual combat

SPIL PLUS 12 (1989)

Jan B. Bedaux

The portraits of Simon van der Stel, first governor of the Cape

SPIL PLUS 13 (1989)

C. le Roux

On the interface of morphology and syntax

SPIL PLUS 14 (1989)

Rudolf P. Botha

The Metaphysics Market. 1 Merchandizing language as matter

SPIL PLUS 15 (1989)

Rudolf P. Botha

The Metaphysics Market. 2 Billing language as behavioural

SPIL PLUS 16 (1991)

Hester Waher

Oor grense, kettings, en lisensies. 'n Sleutel tot Chomsky se

teorie van grammatika

SPIL PLUS 17 (1991)

Rudolf P. Botha

The Metaphysics Market. 3 Selling language as soul

\section{SPIL PLUS 18}

M. Sinclair and W.K. Winckler

Relevance Theory. Explaining verbal communication

\section{SPIL PLUS 19 (1991)}

Rudolf P. Botha

The Metaphysics Market. 4 Pushing language as Platonic (not to mention Popperian) 


\section{SPIL PLUS 20 (1991)}

Rudolf P. Botha

The Metaphysics Market. 5 Stocking language as something social

SPLL PLUS 21 (1992)

TAALWETENSKAP VIR DIE TAALPROFESSIES 1: DEEL A

LINGUISTICS FOR THE LANGUAGE PROFESSIONS 1: PART A

R.P. Botha

Charting the anatomy of linguistic reality

Johann L. van der Walt

Linguistics and second language teaching: An assessment

Gary P. Barkhuizen

What we want from linguistics: A plea from high school

English teachers

Elizabeth de Kadt

Contrastive analysis, pragmatics and language teachers?

Vivian de Klerk

Why language teachers need linguistics

Elaine Ridge

Communicative language teaching: Time for review?

M.S. Odendaal

Error correction in a communicative language teaching framework

Peter Southey

Fossilization in English second language medium

H.W. Broekman

$140-158$

Circular interaction between linguistic departments and language departments

Marianna Visser

Theoretical syntax in second language acquisition research and in second language classroom research

M. Viljoen

Wat is dit wat ons met behulp van ' $n$ taaltoets evalueer?

Norah Haussmann

What exactly are we testing when we claim to be testing mothertongue communicative competence?

J. de Vynck

Taalgebruik en taalbeheersing: twee Franse modelle

J. Keith Chick

A role for linguistics in addressing contextual issues relevant to second language teaching

Christine Anthonissen

The relevance of speech act theory for research on the acquisition of pragmatic competence by second language learners 
Cecile le Roux

The problem of ethnocentric bias in speech act studies: Implications

for language teaching

Kay Mc Cormick

324-337

Sociolinguistics and first language teaching

$338-359$

Jeanne Maartens

The disadvantaged non-mother-tongue speaker as university student

of Afrikaans: Possible solutions to the language lecturer's dilemma

Rosemary Granger

The problem of non-standard utterances used by speakers of English

as a second language at tertiary level

Margaret Inglis

$375-388$

The interrelationship of proficiency in a second language and

understanding of scientific concepts

Ninon Roets

Insette uit die toegepaste linguistiek vir 'n kursus vir akademiese doeleindes

E. Hilton Hubbard

Linguistics as a subversive activity: Exploding myths and

$400-410$

misconceptions in the language classroom

\section{H. Menkveld}

Die problematiek rondom die onderrig van Afrikaans (T1)

411-437

Hildegard van Zweel

Factors influencing the transition from orality to literacy

Myrtle Hooper

The rhetorics of audience consciousness: A dialogic approach to reading Donne in Zululand

Lydia McDermott

Literary analysis and exposition: The second language reader-writer

\section{SPIL PLUS 22 (1992)}

TAALWETENSKAP VIR DIE TAALPROFESSIES 1: DEEL B LINGUISTICS FOR THE LANGUAGE PROFESSIONS I: PART B

\section{LITERêRE KRITIEK EN ANALISE / LITERARY CRITICISM AND ANALYSIS}

Henning H.J. Snyman

Paradigma en parodie

Ina Gräbe

Linguistiese ondersoek en gediganalise: noodwendige verstrengeling of marginale corvleueling?

J.T. von Gruenewaldt

The relevance of linguistic theories in the analysis of literary texts 


\section{VERTALING EN. TEKSWETENSKAP $/$ TRANSLATION AND TEXT LINGUISTICS}

Melinda Sinclair

The effects of context on utterance interpretation: Some questions and some answers

Ferdinand Deist

Bible translation and relevance theory

Gerrie Snyman

The theologian's search for "Meaning": Restraint or liberation of the creative spirit?

C. van Schalkwyk

Vertaling - 'n diskursiewe doenigheid

G. Kroes

Die inhoud en plek van norme in die vertaalpraktyk, vertaalkunde, vertaalkritiek en die vertaalwetenskap

J. du T. McLachlan

Terug na Trap der Jeugd: 'n praklykbeskouing van die resultaat van taalopleiding

Anna-Marie Beukes

Die vertaalberoep en taaibeplanning

Walter K. Winckler

Missing Matthew's meaning. Or: Towards a nodding acquaintance with 'Textual Meaning' (and, maybe, with 'Context' too)

Judith A. Campbell

Semantic representation and the translation of poetry

M.E. Nelson

Perspektiewe uit die tekswetenskap op die vertaling van eiename in 'n kinderboek

Alet Kruger

Die beredeneerde betoog in die afstandonderrig van vertalers

\section{LEKSIKOGRAFIE / LEXICOGRAPHY}

Piet Swanepoel

Leksikografie en linguistiek

F.J. Lombard

Leksikograaf, woordeboekgebruiker en taalwetenskaplike:

'n kongruente of inkongruente driehoek?

John R. Taylor

How many meanings does a word have?

A.E. van Niekerk

Betekenis en gebruik in 'n omvattende woordeboek

Maria Smit

Translating culture-bound words: A problem in bilingual lexicography 
Emst F. Kotzé

Die probleem van grammatikale ekwivalensie by ' $n$ vertalende aanleerderswoordeboek

Klaus Menck

Die woordeboek as hulpmiddel - en nie as struikelblok - in

vreemdetaalonderrig

SPRAAKTERAPIE / SPEECH THERAPY

E. Alant

$407-416$

Die tersaaklikheid van taalwetenskap vir spraakheelkunde

Jenny Pahl

417-438

Speech-language therapy with Zulu clients: Implications for linguistics

\section{INLIGTINGKUNDE / INFORMATION SCIENCE}

L.G. de Stadler and M.W. Coetzer

$439-448$

A morphological parser for Afrikaans

\section{TAALBEPLANNING / LANGUAGE PLANNING}

C.S. Johl

$449-466$

Die relevansie van linguistiek en literatuurwetenskap in 'n post-apartheidgemeenskap

David Brown

$467-471$

Sociolinguistic practice and political change: Critical appraisal of the language atlas of South Africa

Walter McKay

$472-484$

Marginal limitations: Report from a vanishing empire

V. Prabhakaran

The political situation as a factor in shift and maintenance of the Telugu language in South Africa

\section{SPIL PLUS 23 (1994)}

Paul T. Roberge

The formation of Afrikaans 